\title{
Pola Kepekaan Bakteri terhadap Antibiotik di Ruang Rawat Intensif RSPI Prof. Dr. Sulianti Saroso Jakarta
}

\section{The Sensitivity Pattern of Bacteria against Antibiotics at the Intensive Care Unit of Sulianti Saroso Infectious Diseases Hospital Jakarta}

\author{
Putriana Indah Lestari, Ika Susanti dan Huda Rahmawati \\ RSPI Prof. Dr. Sulianti Saroso, JI. Baru Sunter Permai Raya, Sunter, Jakarta Utara, Indonesia
}

\begin{abstract}
Abstrak : Penyakit infeksi merupakan salah satu masalah kesehatan yang penting. Penggunaan antibiotik yang tidak rasional dan tepat guna pada pasien penyakit infeksi beresiko menyebabkan terjadinya resistensi. Tujuan dari penelitian ini yaitu untuk mengetahui pola kepekaan bakteri terhadap antibiotik pada pasien Ruang Rawat Intensif (ICU) RSPI Prof. Dr. Sulianti Saroso (RSPI-SS) Jakarta. Penelitian dilakukan deskriptif dan retrospektif terhadap data sekunder hasil uji kepekaan antibiotik dan jenis bakteri dari 107 pasien dalam kurun waktu 2011. Hasil menunjukkan $68(65,4 \%)$ pasien mendapatkan hasil kultur positif dan uji kepekaan bakteri terhadap antibiotik. Jenis bakteri patogen yang dominan yaitu Acinetobacter baumannii (29,4\%), disusul oleh Pseudomonas aeruginosa (27,9\%), Klebsiella pneumoniae (13,2\%) dan Escherichia coli $(8,8 \%)$. Sebagian besar bakteri pada pasien ICU RSPISS telah berkurang kepekaannya (resisten) terhadap beberapa antibiotik. $A$. baumannii dan $P$. aeruginosa merupakan bakteri yang paling resisten terhadap antibiotik uji. Pola kepekaannya menunjukkan bahwa bakteri patogen mempunyai resistensi tertinggi terhadap erythromycin dan terendah terhadap amikasin.
\end{abstract}

Kata kunci : sensitivitas, antibiotik, rawat inap intensif, Acinetobacter baumannii, Pseudomonas aeruginosa

\begin{abstract}
Infectious diseases is an important health problem. Irrational antibiotics usage is a leading cause in initiating drugs resistances. A preliminary study was conducted on the sensitivity pattern of microorganisms against antibiotics at the intensive care unit of Sulianti Infectious Diseases Hospital Jakarta. Retrospective. Secondary data were collected on the results of antibiotics sensitivity tests and species of microorganisms of 107 patients during the year 2011. Sixty eight (65,4\%) patients were positive on microorganism culture test and tested on antibiotic sensitivity test. Predominance pathogenic species found were Acinetobacter baumannii $(29,4 \%)$, followed by Pseudomonas aeruginosa (27,9\%), Klebsiella pneumoniae (13,2\%) and Escherichia coli $(8,8 \%)$. Most species were less sensitive (resistant) to several antibiotics. The pattern of sensitivity showed that pathogenic microorganisms were the most resistant against erythromycin and the most sensitive antibiotics was amikacin.
\end{abstract}

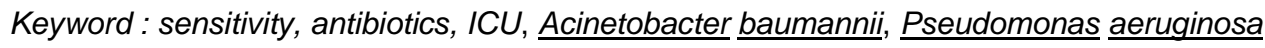

Korespondensi :Putriana Indah Lestari,

Direktorat Pengkajian PI \& PM, RSPI Prof. Dr. Sulianti Saroso,

Jl. Baru Sunter Permai, Jakarta Utara

Telp : (021) 6506559 ext.5001

Email : arsiputri@gmail.com

\section{PENDAHULUAN}

Penyakit infeksi masih merupakan salah satu masalah kesehatan masyarakat yang penting, khususnya di negara berkembang. Salah satu obat andalan untuk mengatasi masalah tersebut adalah antimikroba antara lain antibiotik, antijamur, antivirus dan antiprotozoa. Antibiotik merupakan obat yang digunakan pada infeksi yang disebabkan oleh bakteri. $^{1}$

Pada beberapa negara berkembang, antibiotik diresepkan kepada 44-97\% dari total pasien rumah sakit. ${ }^{2}$ Intensitas penggunaan antibiotik yang relatif tinggi menimbulkan berbagai permasalahan dan merupakan ancaman global bagi kesehatan terutama resistensi bakteri terhadap antibiotik. ${ }^{3}$ Selain berdampak pada morbiditas dan mortalitas, juga memberi dampak negatif terhadap ekonomi dan sosial. Sebesar $84 \%$ pasien rumah sakit di Indonesia mendapat terapi antibiotik dan 38\% diantaranya diberikan secara irrasional dan tidak tepat indikasi. ${ }^{4}$

Bakteri resisten antibiotik terjadi akibat penggunaan antibiotik yang tidak bijak dan penerapan kewaspadaan standar 
(standard precaution) yang tidak benar di fasilitas pelayanan kesehatan. Hasil penelitian Antimicrobial Resistant in Indonesia (AMRIN-Study) menunjukan bahwa pada 781 pasien yang dirawat di rumah sakit didapatkan $81 \%$ E. coli resisten terhadap berbagai jenis antibiotik, yaitu ampisilin (73\%), kotrimoksazol (56\%), kloramfenikol (43\%), siprofloksasin (22\%), dan gentamisin (18\%). ${ }^{5}$

Meskipun munculnya resistensi antibiotik bukan hal baru lagi, namun akibat pengaruh berbagai faktor menyebabkan resistensi bakteri terhadap antibiotik menjadi masalah kesehatan yang kompleks. Jumlah bakteri resisten meningkat dengan cepat dan beberapa bakteri pathogen memiliki resistensi terhadap beberapa antibiotik, bahkan resisten terhadap semua antibiotik. Sebagian bakteri yang telah resisten terhadap antibiotik lini pertama, memerlukan antibiotik lini kedua atau ketiga yang lebih mahal. Banyak faktor yang mempengaruhi munculnya bakteri resisten terhadap antibiotik. Faktor yang penting adalah faktor penggunaan antibiotik dan pengendalian infeksi. ${ }^{6}$ Oleh karena itu, penggunaan antibiotik secara bijaksana merupakan hal yang sangat penting disamping penerapan pengendalian infeksi secara baik untuk mencegah berkembangnya bakteri-bakteri resisten tersebut ke masyarakat

Ruang rawat intensif atau Intensive Care Unit (ICU) adalah suatu bagian dari rumah sakit yang terpisah, dengan staf yang khusus dan perlengkapan yang khusus yang ditujukan untuk observasi, perawatan dan terapi pasien-pasien yang menderita penyakit, cedera atau penyulitpenyulit yang mengancam jiwa atau potensial mengancam jiwa dengan prognosis yang meyakinkan. ${ }^{7}$ ICU merupakan salah satu ruang yang pasiennya banyak menggunakan antibiotik. Penggunaan antibiotik di ICU bertujuan empiris karena dibutuhkan penangan cepat untuk kasus yang berat. $\mathrm{Hal}$ ini menyebabkan bakteri pada pasien ICU rentan mengalami resistensi. Tersedianya pola bakteri dan pola resistensi bakteri pasien yang menjalani perawatan intensif sangat diperlukan sebagai pertimbangan di dalam pedoman pemberian antibiotik secara empirik pada pasien yang menunjukkan gejala dan tanda infeksi. Beberapa bakteri yang menjadi penyebab infeksi di ICU dan sudah mengalami resistensi diantaranya Staphylococcus aureus, Pseudomonas aeruginosa, Klebsiella pneumoniae, Acinetobacter baumannii dan Escherichia coli. ${ }^{8}$

Penelitian ini bertujuan untuk mengetahui pola kepekaan (sensitivitas) bakteri terhadap antibiotik pada pasien ICU RSPI Prof. Dr. Sulianti Saroso (RSPI-SS) Jakarta. Hasil penelitian diharapkan dapat menghasilkan suatu pola kepekaan bakteri terhadap antibiotik di ICU dalam kurun waktu tertentu. Pola kepekaan bakteri terhadap antibiotik yang diperoleh dapat digunakan untuk membuat tatalaksana penggunaan antibiotik yang efektif di ICU RSPI-SS Jakarta dan sebagai dasar terapi awal antibiotik di ICU sehingga kualitas pelayanan kepada pasien dapat ditingkatkan.

\section{METODE PENELITIAN}

Penelitian dilakukan di Instalasi Laboratorium RSPI-SS Jakarta pada tahun 2012. Penelitian ini merupakan penelitian deskriptif observasional dengan metode potong lintang (cross sectional) menggunakan data sekunder secara retrospektif. Objek penelitian adalah hasil laboratorium pasien rawat inap di ICU yang menerima antibiotik dan mempunyai hasil uji kepekaan bakteri terhadap antibiotik.

Populasi adalah semua catatan medik pasien yang menerima antibiotik, telah dirawat di ICU dan mempunyai hasil uji bakteri dan kepekaan. Sampel adalah catatan medik pasien yang menerima antibiotik, mempunyai hasil uji bakteri dan kepekaannya terhadap antibiotik di ICU dalam kurun waktu 1 Januari-31 Desember 
2011. Hasil penelitian dianalisis dan disajikan dalam bentuk tabel menggunakan Microsoft Excel tahun 2007.

\section{HASIL DAN PEMBAHASAN}

Hasil menunjukkan dari 107 data rekam medik pasien ICU yang menerima antibiotik, 68 (65,4\%) diantaranya memiliki hasil kultur positif dan memiliki hasil uji kepekaan antibiotik. Jenis spesimen yang diuji pola kepekaan antibiotik tertinggi yaitu sputum $(41,2 \%)$, disusul oleh cairan selang ETT $(32,4 \%)$ dan darah (19,1\%). Sebagian besar hasil kultur positif adalah golongan bakteri gram negatif $(92,6 \%)$ dan hanya sebagian kecil yang merupakan golongan gram positif (7,4\%). Bakteri yang paling dominan yaitu Acinetobacter baumannii (29,4\%), disusul oleh Pseudomonas aeruginosa (27,9\%), Klebsiella pneumoniae (13,2\%) dan Escherichia coli (8,8\%; Tabel 1).

Tabel 1. Frekuensi bakteri yang diisolasi dari pasien ICU RSPISS

\begin{tabular}{|l|l|l|}
\hline No & Jenis Bakteri & $\begin{array}{l}\text { Jumlah } \\
{[\text { frekuensi }} \\
(\%)]\end{array}$ \\
\hline 1 & $\begin{array}{l}\text { Acinetobacter } \\
\text { baumannii }\end{array}$ & $20(29,4)$ \\
\hline 2 & $\begin{array}{l}\text { Pseudomonas } \\
\text { aeruginosa }\end{array}$ & $19(27,9)$ \\
\hline 3 & Klebsiella pneumoniae & $9(13,2)$ \\
\hline 4 & Escherichia coli & $6(8,8)$ \\
\hline 5 & $\begin{array}{l}\text { Staphylococcus } \\
\text { epidermidis }\end{array}$ & $3(4,4)$ \\
\hline 6 & $\begin{array}{l}\text { Pseudomonas } \\
\text { maltophilia }\end{array}$ & $2(2,9)$ \\
\hline 7 & Staphylococcus aureus & $2(2,9)$ \\
\hline 8 & Burkholderia cepacia & $1(1,5)$ \\
\hline 9 & $\begin{array}{l}\text { chryseobacterium } \\
\text { meningosepticum }\end{array}$ & $1(1,5)$ \\
\hline 10 & Enterobacter cloacae & $1(1,5)$ \\
\hline 11 & Pseudomonas diminuta & $1(1,5)$ \\
\hline 12 & Pseudomonas putida & $1(1,5)$ \\
\hline 13 & Seratia sp & $1(1,5)$ \\
\hline 14 & $\begin{array}{l}\text { Xanthomonas } \\
\text { malthophilia }\end{array}$ & $1(1,5)$ \\
\hline \multicolumn{2}{|c|}{ Total } & $68(100,0)$ \\
\hline
\end{tabular}

Sumber data: Laporan Mikrobiologi Instalasi Laboratorium RSPI-SS tahun 2011

Temuan ini hampir sama dengan penelitian di India dalam hal jenis bakteri yang paling dominan pada pasien di ICU, yaitu berturut-turut dari yang paling dominan adalah $A$. baumannii (24,0\%), kemudian disusul oleh $K$. pneumoniae $(22,0 \%)$ dan $P$. aeruginosa $(20,0 \%) .{ }^{9}$ Penelitian serupa pada pasien ICU RS Fatmawati Jakarta, telah dilaporkan dengan hasil $P$. aeruginosa (26,5\%), $K$. pneumoniae $(15,3 \%), \quad S$. epidermidis $(14,9 \%)$ dan Enterobacter aerogenes $(13,3 \%)$ sebagai bakteri yang paling dominan ditemukan. ${ }^{10}$ Sedangkan di RS Kariadi Semarang bakteri yang mendominasi pada pasien ICU adalah $P$. aeruginosa $(50,9 \%)$, E. aerogenes $(37,5 \%)$ dan E. coli $(8,7 \%) .^{11}$

Seluruh bakteri sudah berkurang kepekaannya terhadap antibiotik yang diujikan, sebagian besar resisten terhadap beberapa antibiotik. Sebagian besar menunjukkan kepekaan yang paling rendah terhadap erythromycin $(0,0-25,0 \%)$ dan ampicillin (0,0-37,5\%; Tabel 2). Selain A. baumannii, mayoritas bakteri yang masih relatif sensitif dengan menunjukkan presentase kepekaan yang relatif sedang tinggi $(>50,0 \%)$, adalah terhadap amikasin $(30,0-100,0 \%)$, imepenem $(30,0-83,3,0 \%)$ dan norfloxacin (5,0-75,0\%). Bakteri yang paling tinggi tingkat kepekaannya yaitu $K$. pneumoniae yang masih sensitif terhadap $15(88,2 \%)$ antibiotik uji. Sedangkan E. coli menjadi satu-satunya bakteri yang masih sangat sensitif $(0,0 \%)$ terhadap amikasin.

Pola kepekaan $A$. baumannii menunjukkan kecenderungan mengalami multi-drug resistant (MDR) dengan persentase sensitivitas sebesar 0,0-20,0\% pada sebagian besar antibiotik yang diujikan. Antibiotik yang paling sensitif terhadap $A$. baumannii pada penelitian ini adalah pada golongan sulfametoxazoletrimethoprim, meskipun dengan persentase sensitivitas yang sudah cukup rendah (35,0\%). Hingga saat ini, $A$. baumannii masih menjadi salah satu bakteri yang sulit untuk dikendalikan karena tingginya potensi resisten terhadap berbagai antibiotik. $^{12} A$. baumannii dilaporkan telah mengalami MDR terhadap imipenem, ${ }^{13}$ amikacin dan colistin. ${ }^{14}$ 
Tabel 2. Kepekaan (sensitivitas) bakteri dominan terhadap antibiotik pada pasien ICU RSPI-SS (\%)

\begin{tabular}{|c|c|c|c|c|}
\hline Antibiotik & $\begin{array}{l}\text { A. baumannii } \\
(\mathrm{n}=20)\end{array}$ & $\begin{array}{l}P . \text { aeruginosa } \\
(\mathrm{n}=19)\end{array}$ & $\begin{array}{l}\text { K. pneumoniae } \\
(\mathrm{n}=9)\end{array}$ & $\begin{array}{l}\text { E. coli } \\
(\mathrm{n}=6)\end{array}$ \\
\hline Amikasin (AK) & 30.0 & 68.4 & 77.8 & 100.0 \\
\hline Amoxixilin (AMC) & 5.0 & 50.0 & 50.0 & 40.0 \\
\hline Ampicillin (AM) & 10.5 & 0.0 & 37.5 & 16.7 \\
\hline Aztreonam (ATM) & 20.0 & 0.0 & 87.5 & 40.0 \\
\hline Cefotaxime (CTX) & 10.5 & 10.0 & 75.0 & 20.0 \\
\hline Ceftazidime (CAZ) & 10.0 & 41.2 & 75.0 & 83.3 \\
\hline Ceftriaxone (CRO) & 10.0 & 50.0 & 75.0 & 20.0 \\
\hline Chloramphenicol (C) & 0.0 & 16.7 & 55.6 & 66.7 \\
\hline Ciprofloxacin (CIP) & 5.3 & 33.3 & 66.7 & 33.3 \\
\hline Erythromycin (E) & 25.0 & 0.0 & 0.0 & 0.0 \\
\hline Gentamycin (GM) & 15.0 & 33.3 & 77.8 & 33.3 \\
\hline Imepenem (IPM) & 30.0 & 50.0 & 83.3 & 66.7 \\
\hline Kanamycin (K) & 10.0 & 0.0 & 62.5 & 40.0 \\
\hline Nalidixic Acid (NA) & 5.0 & 0.0 & 75.0 & 40.0 \\
\hline Norfloxacin (NOR) & 5.0 & 50.0 & 75.0 & 60.0 \\
\hline Sulfa/trimeto (SXT) & 35.0 & 16.7 & 66.7 & 16.7 \\
\hline Tetraciclin (TE) & 10.0 & 26.3 & 66.7 & 33.3 \\
\hline
\end{tabular}

Sumber data: Laporan Mikrobiologi Instalasi Laboratorium RSPISS tahun 2011

$P$. aeruginosa pada pasien ICU RSPISS telah mengalami MDR terhadap ampicillin, aztreonam, erythromycin, kanamycin dan nalidixid acid. Kasus MDR $P$. aeruginosa telah banyak dilaporkan di berbagai negara dengan antibiotik yang berbeda-beda. ${ }^{15}$ Hasil penelitian di Kanada, menunjukan bahwa $P$. aeruginosa merupakan yang paling banyak mengalami MDR terhadap lebih dari 3 antibiotik termasuk cefepime, piperacillin-tazobactam, meropenem, amikacin dan ciprofloxacin. ${ }^{16}$ Sementara di Thailand, dilaporkan bahwa $P$. aeruginosa juga resisten terhadap imipenem. ${ }^{17}$ Meningkatnya kasus MDR $P$. aeruginosa disebabkan oleh transmisi silang (cross-transmission) di rumah sakit. ${ }^{18}$ MDR $P$. aeruginosa dilaporkan dapat meningkatkan resiko kematian pada pasien yang mengalami bakterimia. ${ }^{19}$ Saat ini, beberapa antibiotic yang dilaporkan bersifat antipseudomonas antara lain antipseudomonal penicillin (penicillin carboxy dan ureido), antipseudomonal cephalosporin, monobactam, quinolone, aminoglycoside, dan carbapenem. ${ }^{20}$

\section{KESIMPULAN DAN SARAN}

Sebagian besar bakteri pada pasien ICU RSPISS telah resisten terhadap beberapa antibiotik. A. baumannii dan $P$. aeruginosa merupakan bakteri yang paling resisten terhadap sebagian besar antibiotik uji. Pola kepekaannya menunjukkan bahwa bakteri patogen yang ditemukan mempunyai resistensi tertinggi terhadap erythromycin dan terendah terhadap amikasin

\section{UCAPAN TERIMA KASIH}

Penulis mengucapkan terima kasih kepada drg. James Johnson S., MPH selaku Kepala Seksi Pengkajian Resistensi, segenap staf di lingkungan Instalasi Laboratorium RSPISS dan Prof. Dr. Gono Semiadi untuk bimbingan dalam menyusun artikel ini.

\section{DAFTAR PUSTAKA}

1. Chapin KC. 2007. Principles of Stains and Media. In Murray PR, Baron EJ et all. Principles of Clinical Microbiology. American Society of Microbiologist, Washington, 182-91.

2. Hu, S., Liu X dan Peng Y. 2004. Assessment of antibiotic prescription in hospitalized patients at a Chinese university hospital. J Infect 48: 117118.

3. Kemenkes RI. 2011. Pedoman Umum Penggunaan Antibiotik. Peraturan 
Menteri Kesehatan RI nomor 2406/MENKES/ PER/XII/201I.

4. Hadi, U., Duerink DO, Lestari ES, Nagelkerke NJ, Keuter M. dan Huis in't Veld D. 2008. Audit of antibiotic Prescribing in two governmental teaching hospitals in Indonesia. Clin Microbiol Infect 14; 698-707.

5. Suharjono, dkk. 2009. Studi penggunaan antibiotik pada Penderita rawat inap pneumonia (penelitian di sub departemen anak Rumkital dr. Ramelan surabaya. Majalah IImu Kefarmasian VI (3) ; 142-155.

6. Hadi, U., Resistensi Antibiotik, Buku Ajar IImu Penyakit Dalam, 2006, Pusat Penerbitan departemen IImu Penyakit Dalam FKUI Jakarta.

7. Kemenkes RI. 2010. Pedoman Penyelenggaraan Pelayanan Intensive Care Unit (ICU) di Rumah Sakit. Keputusan Menteri Kesehatan RI Nomor 1778/ MENKES/ SK/XII/2010.

8. Vincent, JL., Rello J., Marshall J., Silva E., Anzueto A. dan Martin CD. 2009. International study of the prevalence and outcomes of infection in intensive care units. JAMA 302(21): 2323-2329.

9. Khan, MA. 2012. Bacterial Spectrum and Susceptibility patterns of Pathogens in ICU and IMCU of a Secondary Care Hospital in Kingdom of Saudi Arabia. International Journal of Pathology 10(2); 64-70.

10. Radji, M., S. Fauziah, N. Aribinuko. 2011. Antibiotic Sensitivity Pattern Of Bacterial Pathogens In The Intensive Care Unit Of Fatmawati Hospital, Indonesia. Asian Pac J Trop Biomed $1(1)$; 39-42.

11. Winarto. 2009. Prevalence of extended-spectrum -lactamases (ESBL)-bacteria of blood isolates in Dr. Kariadi Hospital Semarang 20042005. Media Medika Indosiana 43(5); 260-267.

12. Fishbain, J dan Anton Y. Peleg. 2011. Treatment of Acinetobacter Infections. Oxford Journals, Medicine, Clinical Infectious Diseases 51(1);79-84.

13. Kuo, H., Kai-Chih Chang , Jai-Wei Kuoe, Hui-Wen Yueha dan Ming-Li Liou. 2012. Imipenem: a potent inducer of multidrug resistance in
Acinetobacter baumannii. International Journal of Antimicrobial Agents 39; 33- 38.

14. Francesco, MA., G. Ravizzola, L. Peroni, C. Bonfanti dan N. Manca. 2013. Prevalence of multidrugresistant Acinetobacter baumannii and Pseudomonas aeruginosa in an Italian hospital. Journal of Infection and Public Health 6;179-185.

15. Tam, VH., Kai-Tai Chang, Kamilia Abdelraouf, Cristina G. Brioso, Magdalene Ameka, Laurie A. McCaskey. 2010. Prevalence, Resistance Mechanisms, and Susceptibility of Multidrug-Resistant Bloodstream Isolates of Pseudomonas aeruginosa. Antimicrob. Agents Chemother. 54(3); 1160-1164.

16. Zanel, GG., DeCorby M, Laing N, Weshnoweski B, Vashisht R. dan Tailor F. 2008. Antimicrobial-resistant pathogens in intensive care units in Canada: results of the Canadian National Intensive Care Unit (CANICU) study, 2005-2006. Antimicrob Agents Chemother 52(4); 1430-1437.

17. Cholley, P., Michelle Thouverez, Didier Hocquet, Nathalie van der MeeMarquet, Daniel Talon dan Xavier Bertrand. 2011. Most MultidrugResistant Pseudomonas aeruginosa Isolates from Hospitals in Eastern France Belong to a Few Clonal Types J. Clin. Microbiol. 49(7); 2578-2583.

18. Tumbarelo, M., E. Repetto, E.M Trecarichi, C. Bernardini dan M. Bassetti. 2011. Multidrug-resistant Pseudomonas aeruginosa bloodstream infections: risk factors and mortality. Epidemiology and Infection 139(11) ; 1740-1749.

19. Hirsch, EB. dan Vincent H. Tam. 2010. Impact of Multidrug-resistant Pseudomonas aeruginosa Infection on Patient Outcomes. Expert Rev Pharmacoeconomics Outcomes Res. 10(4); 441-451.

20. Giamarellou, H. dan Antoniadou, A. 2001. Antipseudomonal Antibiotics. Med Clin North Am. 85(1); 19-42. 